\title{
EchoGéo
}

$17 \mid 2011$

Activités extractives

\section{How can mental maps, applied to the coast environment, help in collecting and analyzing spatial representations?}

\section{Servane Gueben-Venière}

\section{(2) OpenEdition}

Journals

Édition électronique

URL : https://journals.openedition.org/echogeo/12625

DOI : 10.4000/echogeo. 12625

ISSN : 1963-1197

Éditeur

Pôle de recherche pour l'organisation et la diffusion de l'information géographique (CNRS UMR 8586)

Référence électronique

Servane Gueben-Venière, "How can mental maps, applied to the coast environment, help in collecting and analyzing spatial representations? », EchoGéo [En ligne], 17| 2011, mis en ligne le 27 septembre 2011, consulté le 10 août 2021. URL : http://journals.openedition.org/echogeo/12625 ; DOI : https:// doi.org/10.4000/echogeo.12625

Ce document a été généré automatiquement le 10 août 2021.

EchoGéo est mis à disposition selon les termes de la licence Creative Commons Attribution - Pas d'Utilisation Commerciale - Pas de Modification 4.0 International (CC BY-NC-ND) 


\title{
How can mental maps, applied to the coast environment, help in collecting and analyzing spatial representations?
}

\author{
Servane Gueben-Venière
}

\section{Introduction}

1 The mental map is a graphical way of expressing a subjective reality of space, that is to say the way in which an individual imagines a part of space. This tool thus facilitates the collection of spatial representations that the individuals make of their environment. These spatial representations, or cognitive representations of space, are fed by mental representations, or individual ones (making reference to real-life experience, to the education, to the culture of the individual), but also by social representations, shared by a socio-professional group (Paulet, 2002). For a long time discussed by the geographers, the interest of the analysis of representations in geography is now being accepted: the analysis of perceptions and representations through which individuals and groups of individuals "read the territory", appears as necessary to better understand their practices. (Bailly, Ferrier, 1986, in Paulet, 2002). The controversies and the difficulties connected to the mind maps' analysis could suggest that this tool would finally be abandoned by the discipline. However, this is not the case. Indeed, mental maps have now being a source of renewed interest in cultural, social and humanist geography for the past few decades. More recently, they have found their way with environmental geography. 


\section{The use of mind maps in environmental geography: a new application}

2 In 1913, Charles Trowbridge, was one of the first to make the hypothesis of a link between the capacity of some individuals to find their bearings and to move, and the existence of 'mental maps' as a support for this capacity (Gould et al., 1984). The aim was to understand the mental images that affected the transfer of individuals. In the 1950s, the work of K. Lynch, architect and town planner, transformed the contribution of spatial representations into a real decision-making tool for urban planners (Lynch, 1960). The mental maps collected thus revealed not only the logic of the movements of city dwellers and the borders of neighbourhoods, but also the strategic points of the drawn areas, and the markers and reference points of the city users. This then, highlights what A. Frémont would conceptualise some years later as 'lived space' (Lynch, 1960; Frémont, 1999). P. Gould and R. White showed interest in the individuals' mind images being able to explain their preferences for a place, a region or a country. G. Di Méo would later take this into the concept of 'imagined space' and of 'space of life'. He would define this as 'the space frequented and crossed by everyone with a minimum of regularity' (Di Méo, 1998). The two American geographers also used mental maps to measure the knowledge and the ignorance of individuals (Gould et al., 1984). In the 1970s, cultural, social and humanist geography granted a first place to the analysis of the perceptions - 'functions by which the mind represents objects in their presence' (Bailly, in Di Méo, 1991) - and representations which consist of 'a perception modelled by the psyche' (Piaget, Inhelder, in Di Méo, 1991). In other words, these geographical trends assert that subjectivity needs to be taken into account in the study of territories. If this position has been mainly discussed, even disputed $^{1}$, it seems nowadays mainly accepted by the discipline. Indeed, J-P. Paulet insists on a mayor point at the very beginning of his book Les représentations mentales en géographie': 'mental representations' analysis is not a geographical trend among others... It is the essence itself of the discipline. Every big questions must take into account the way men 'see' their environment. [...] Human action can be explained by the deformed vision of the world, connected to a cultural dimension' (Paulet, 2002). P. Claval, in Géographie culturelle. Une nouvelle approche des sociétés et des milieux ${ }^{3}$, dedicates a whole chapter to the individuals' orientation and to their capacity of 'finding their bearings'. The author uses several examples of mental maps ${ }^{4}$, and shows how the analysis of these maps helps in collecting boundaries and subjective signification of places (Claval, 2003).

3 Nevertheless, the difficulties inherent in the interpretation of mental maps have always led the geographers to handle this tool with extreme caution, even with a certain reluctance. The warnings are numerous and insistent concerning implementation and analytical work on mind maps. Thus H. Gumuchian reminds us that the 'relatively new fashion for using mental maps in research (...) should not allow us to forget that materials are to be handled with caution; this requirement is all the stronger as, theoretically, the approach of mental mapping remains hardly sketched' (Gumuchian, 1991). R. Dows and D. Stea ask the question of the interpretation of spatial distortions, of the 'oversights' or the 'voids' appearing on mind maps: 'Yet all cognitive maps depict discontinuous surfaces' (Down et al., 1973). How, indeed, can these spatial discontinuities be interpreted? At last, J-F. Staszack underlines an important bias connected to the drawing itself: 'the drawn map [freehand] does not always show a good image of the cognitive structure, but it can, for example, 
measure a capacity to draw and to map' (Staszak, 2003). Yet, according to Moser et al., the 'fear of drawing' mainly concerns the elderly and those from a modest background (Moser et al., 2003). Indeed a particular attention must be given to the profile of those invited to draw. This graphical tool can function adequately as a means of complementing interviews. Consequently, the analysis of spatial representations does not only depend on mind maps. It is in this way that the use of mental maps has been applied in this study.

4 However, since the turn of the new millennium, and despite the difficulties introduced, mind maps are used again by geographers, especially in the field of environmental geography. Thus, F. Péron, in an article dealing with 'Social functions and subjective dimensions of island spaces', uses mind maps to highlight the differences between spatial representations of an inhabitant of Ouessant Island, a person with a second home there and a visitor to the island (Péron, 2005). The author questions the socio-spatial relationship that three individuals maintain, according to the degree of appropriation they feel towards the island territory. In 2008, Irish researchers employed mind maps in a new way, trying to analyze the relationship not between an individual, but rather between a professional group to a given environment. The new character of this approach leads also onto the fact that very few studies using mind maps have been explored yet in a more 'natural' framework (Kenna et al., 2008). Their objective was to report the importance of vernacular knowledge (referred to by the authors as LEK or Local Ecological Knowledge) of fishermen working on North Ireland Lough Neagh, by measuring their knowledge of the lakeside environment. In order to measure this, the researchers have analyzed the spatial representations each fisherman creates in his environment (bathymetric variations, types of soil, location of sandbanks and of the currents etc), and then 'compiled' the mental maps collected in order to create one unique map expressing the degree of knowledge and of distinctness of the environment they are working and living in. By comparing them with 'scientific' maps obtained by using radiowaves and sonars, this experiment revealed the precision of the information given by the fishermen. From these results two particularly interesting points have emerged. On the one hand, the concordance between the different spatial representations collected enable one unique mental map to be shown, the result of which should not be seen in the adding up of individual knowledge, but in the common knowledge of a social group precisely identified by this shared characteristic. On this point, the authors confirm moreover the comments of P. Gould and R. White: 'while every view is unique... there may be considerable overlap between the mental maps of people. The more homogeneous the group in terms of age and experience, the more overlap we might expect between the mental images' (Gould et al., 1974). On the other hand, the practical experience of these fishermen, that is to say, the uses they make of this place, highlights, through the use of the mental maps, the precise knowledge they have of their environment. So, the special representations they create of their local environment allow them to make decisions which are useful for carrying out their trade, decisions their environment allows. Transposed to a national scale, this second result also concurs with the comments of P. Gould and R. White: 'the men and the women who are taking decisions related to national space and the inhabitants should be conscious of their own spatial and regional space conditioning, (...), just as the psychoanalyst must be conscious of his own psychological history and of the way it can affect his or her judgment' (Gould et al., 1984). 
5 It is in this way that mind maps appearing in the poster have been employed. The latter outlines the key stages of the evolution of the management choices made by engineers. With worldwide reputation for their knowledge and know-how, and long famed for their exclusively technical approach to marine erosion and submersion problems, Dutch engineers are now proposing softer solutions for coastal management, taking into account not only security issues but also social, economic and ecological ones, as well as a long-term vision. Now the evolution of this coastal management can find foundations in the analysis of representations that this professional group make of geographical notions such as the coast, the boundaries of which are vague and of which the definitions are as numerous as the uses made of this space between land and sea. Contrary to the study of J. McKenna et al., the aim here is not to measure the exact knowledge of the engineers, but more to understand how engineers imagine the coast they are managing. In other words, the question is to know if the addition of mental (and hence individual) representations of the engineers concerned can highlight social representations, that is to say representations shared by this professional group and, consequently, characterising it.

\section{Mental maps: a tool for collecting mind representations}

Generally speaking, there are two ways of collecting spatial representations using mind maps ${ }^{5}$. Firstly by asking someone to draw a part of space on a blank sheet of paper; secondly on a basic map showing a minimum of information (isoclines, urban areas and names of cities, boundaries and coastline). This second option has been chosen. By proposing a basic map of The Netherlands (in A3 size for greater legibility), the advantage was double:

- To reduce the part of distortions due to the difficulty of drawing on a blank sheet of paper.

- To facilitate the 'compilation' of the collected mind maps and so the analysis of the results as will be set out in the next paragraph.

7 The mind maps collected have been in a way supervised. By drawing the coastline on the basic maps, the aim was to collect the limits given to the coast by the interviewees and determine how far it extends inland and out to sea. The question is, do engineers consider the coast they manage as a system composed by a backshore and an offshore? (Corlay, 1995) 


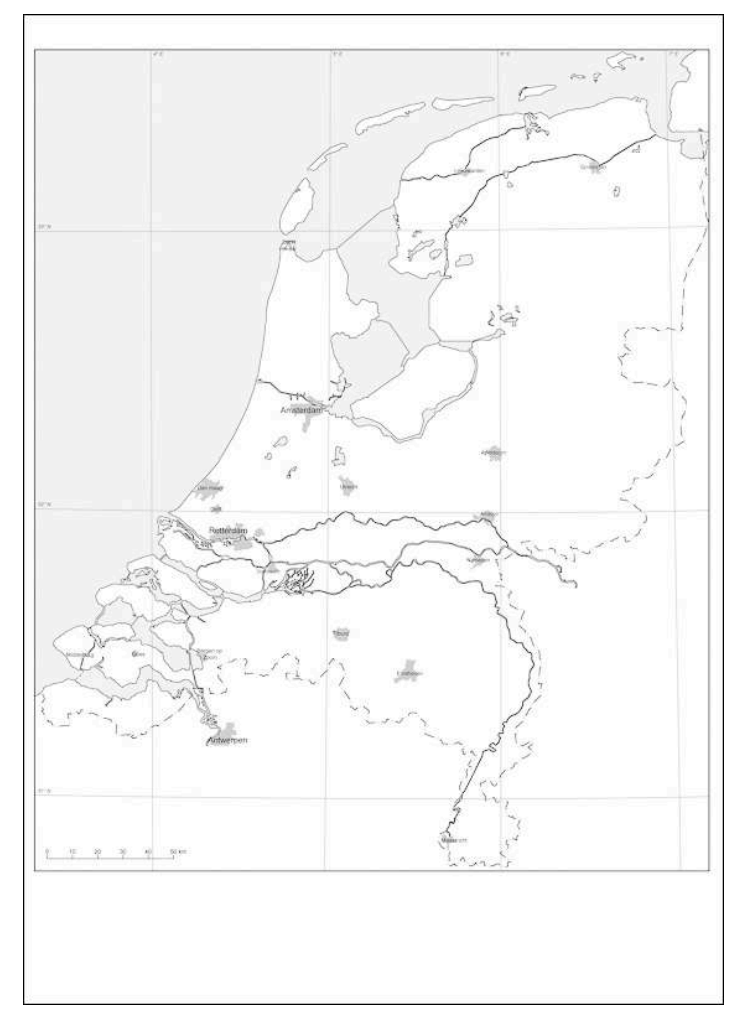

The Dutch coast is composed of three distinguished geomorphologic areas: in the south, the delta of Zeeland, in the centre, the dunes area, in the north, the Wadden sea area.

Authors: S. Gueben-Venière, G. Decroix

Once this methodological choice has been made, mind maps seem to be an excellent tool to collect representations, as far as they are used to complement semi-directed interviews. Interviewees were asked to provide a verbal definition of 'coast'. They were then asked to draw it according to the following instruction: 'on this basic map at the national scale, can you draw what corresponds to the coast according to you?' The complementary nature of the discussion and of the drawing on one hand allows one to delve deeper into the definition proposed for the coast, and on the other to highlight a certain number of contradictions. Here are three examples: 'What definition would you give for the coast?

- 'Well... there are three types of coast in The Netherlands : the area of the Wadden Sea in the North, the dunes in the centre and the delta of Zeeland in the South. So the Dutch coastal area is all that together!'While the interviewee's examples of the characteristics of the Dutch coast were certainly valuable information, he did not define it. The fact of then requesting a drawing of the coast on a basic map produced a more precise picture of its terrestrial and marine limits, which the simple discussion did not offer 6 . In this way the mind map presents the opportunity to by-pass difficulties while speaking.

10 - 'The coast? This is the coastline!'

The definition given by the interviewee seems to be simple and almost obvious. Nevertheless, when he took a pen to draw this coastline, he had to face a difficulty he had not anticipated: how to represent graphically the coastline in the area of the delta of Zeeland? Where does the marine limit associated with the coast end, and where do 
the banks of the Westerschelde begin? The difficulty also re-appears in the northern area: should the islands of the Wadden Sea be excluded? Or should they be included, and consequently be accepted the idea that the coast cannot systematically be reduced to a line, but rather corresponds to an 'area'? It would not be unfair to remark that without the aid of the mental maps, the interviewee would have struggled to spatialize his representations of the coast.

11 - 'The coastal area corresponds to embankments and dunes'

If the interviewer contents himself with this verbal answer, the coastal area so defined seems to be summed up as an area composed of terrestrial and visible elements (the embankments: a product of civil engineering, and the dunes, a geomorphologic unit). The submission of the basic map allowed the interviewee to develop his thoughts and it was easy for this person to represent dunes on the map and so to delimit the terrestrial limits of the coastal area. Very quickly, however, the interviewee realised that the coastal area could not be limited to this terrestrial zone and that the sea was an intrinsic part of the coastal area. The confrontation with the map enabled the interviewee to widen the sea limit of the coastal area up to 20 meters in depth. Indeed, when sand-replacing work is carried out to combat dune erosion, the sand is removed beyond a depth of 20 metres. This figure (20 meters) tallies with Dutch scientific belief that the natural evolutionary dynamic of the dunes generally has an effect up to a depth of 20 metres. The spatialization effort required of the interviewee made it possible to obtain crucial information. Without having spontaneously expressed it verbally, he eventually tackled the dynamic aspect of the coastline and no longer thus defined it as a coastal area, but rather as a dynamic system to be envisaged in its entirety. The transition to the practice of managing the coast was perfect!

\section{Mental maps: a tool for analyzing collected representations}

12 Mind maps are not only helpful in collecting spatial representations, but they function also as an analytical tool of particular interest for the geographer. A way of dealing with the graphic results obtained consists of 'compiling' the usable mental maps. This method was used by J. McKenna et al., quoted previously, to measure the knowledge of a socio-professional group about its work environment (the lake fishermen of Lough Neagh), and was described by E. Bonnet in a study linked to industrial risks and to the integration of representations into the evaluation of the vulnerability of the territory of the Seine estuary (Bonnet, 2004). In order to do this, mind maps were integrated into a GIS (Geographical Information System) and digitized one by one. A program then calculated the superimposition of the drawings, highlighting the occurrence of the areas described by the population as being zones of potential risk. This same procedure was used to analyze the mind maps in this current study. Their superimposition permitted the establishment of an 'average' mind map of the representations shared by the professional group of engineers. 
Illustration 2 - The limits of the coast according to the engineers

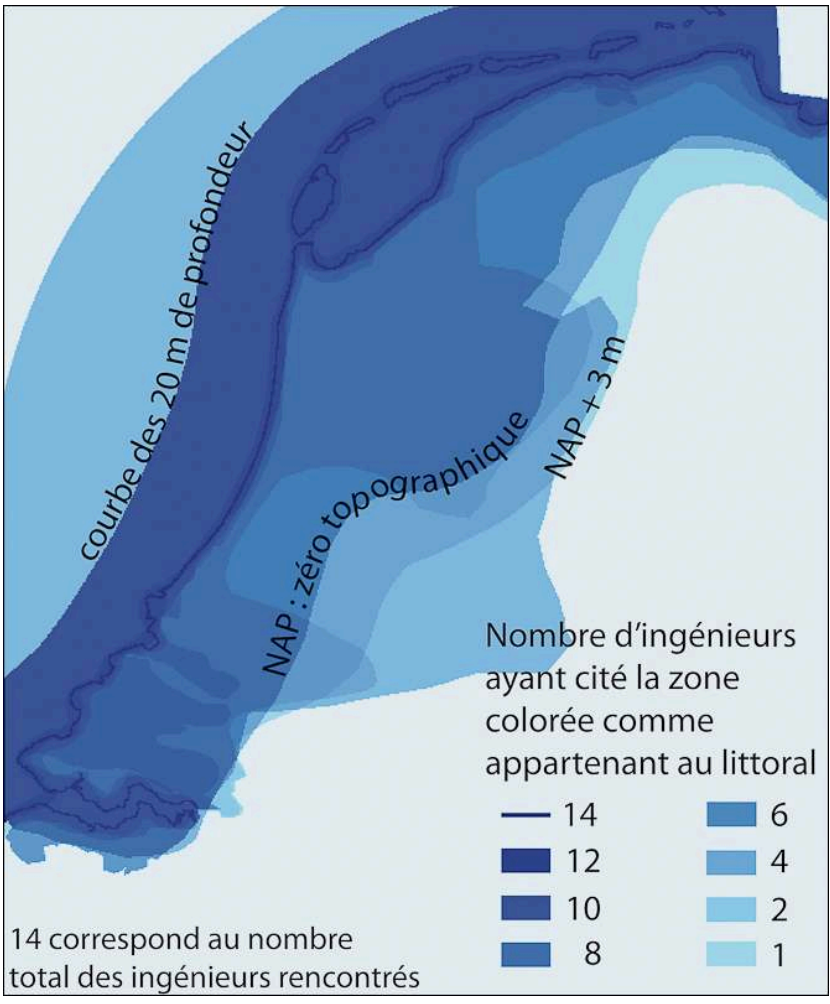

Authors : S. Gueben-Venière, J.-F. Cuenot.

Illustration 3 - The limits of the coast according to ecologists and other scientists

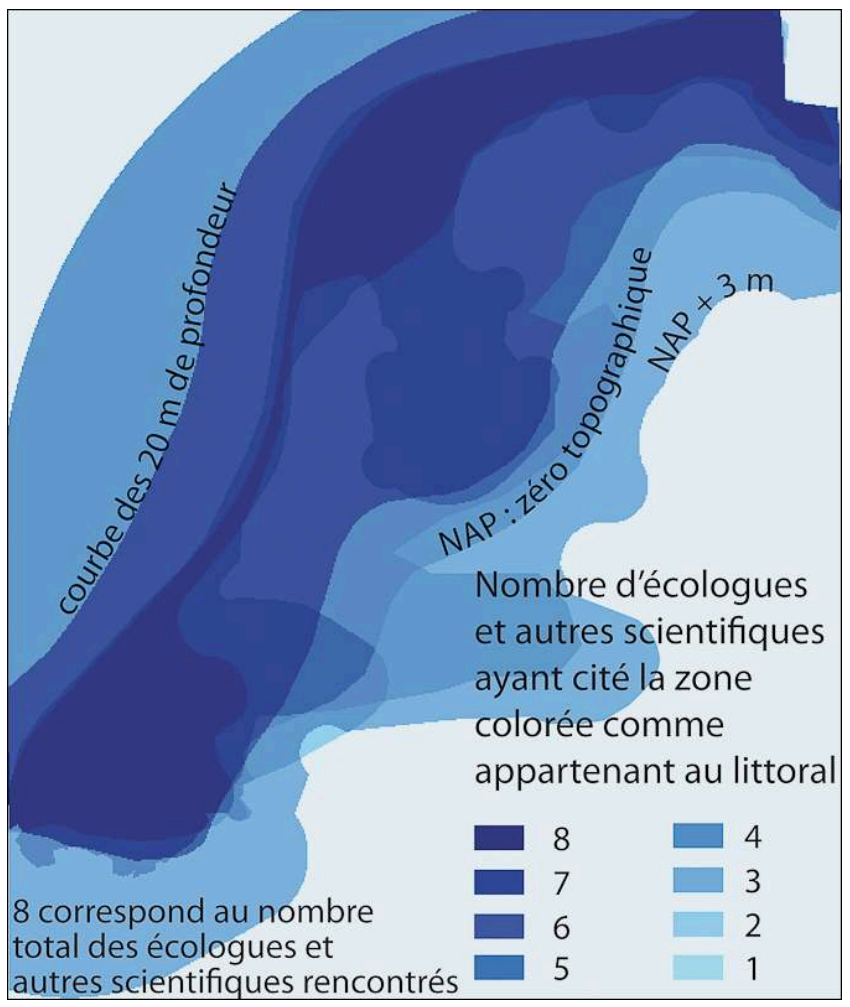

NAP: Normal Amsterdam Peil: Normal Amsterdam Level

Authors: S. Gueben-Venière, J-F. Cuenot 
Thus, the majority of the engineers are no longer considering only a coastline but rather a coastal area ( 8 on 14) and an underwater volume (12 out of 14). Completed by the analysis of the interviews, the mind maps have helped to highlight the dynamic aspects of the coastal area system, accepted by the majority of the engineers met. In addition, the superimposition of mind maps produced by ecologists and other scientists (geomorphologists, geologists...) allowed a comparison between the representations of the latter and of the engineers. These two 'average maps' show similarities. The characteristics of the 'engineers' coast' are similar to those of the ecologists and other scientists. The opposition between a linear and static vision of the coast, for a long time attributed to engineers, and the opposition, greater and more systemic attributed to ecologists and other scientists, is becoming less marked. This acknowledgement demonstrates that Dutch engineers are becoming more open to dialogue, a result of an evolution in the way of thinking about coastal management. In 1955, when the first Delta commission was created to work on the famous Delta $\mathrm{Plan}^{7}$, it consisted exclusively of engineers. Fifty years later, the multidisciplinary Veerman commission made public Delta Plan 2. The strong and innovative idea of this plan is based on the fact of living with water in order to be better protected and not to push the sea back behind dams as the first Delta Plan suggested.

Finally, resorting to mind maps can also permit a closer analysis of the profiles of engineers themselves. Indeed, for several decades, the training of engineers has become more diverse, and its content has evolved. Thus, the correlation between university training, its contents, the date of graduation and the boundaries that engineers give to the coast is giving information about the evolution of critical opinion on this and consequently about the practices of engineers in charge of coastal management. Generally speaking, engineers who have recently graduated, having had training with the coastal environment and ecology as options spontaneously, tend to widen their definition of the coast and do not limit it to the basic coastline. This result thus helps to better understand the alternative solutions to the systematic raising of embankments, now being proposed by engineers. The example - still at the stage of a project today - presented in the poster, gives priority to a management of marine submersion risk by creating a buffer area between land and sea, taking into account a dynamic coastal system and accepting partial and temporary submersion of the first embankment line.

\section{Conclusion}

15 Resorting to mind maps in the field of environmental geography is relatively new. Mainly used to highlight mental or individual representations, this graphical tool also offers the possibility of revealing social representations shared by a professional group. This article set out to ask how mental maps can help describe how technicians responsible for the management of coastal territory experience this notion of geographical. In spite of their difficult interpretation, mind maps can nevertheless help in collecting and analyzing representations, as far as they are used to complement interviews. Their processing by superimposition allowed us to obtain an 'average' mental map, revealing spatial representations engineers have of the coast. It was possible then to compare this final visual document to the ones produced by another professional group - the ecologists involved in coastal management - to better 
highlight the characteristics of the first ones. Moreover, correlating the type of training of the interviewees (the year and the university from where they graduated) to the content of individual mind maps can be of great interest. This analysis thus permitted us to better define their profile and consequently to better explain the connection between representations of the coast and management practice. At last, the combination of the verbal interview and of mental maps made possible a selfassessment of the interviewees. In some cases, this also led them to question their approach to the coast. The implications of using this method are such that it can now be considered a fruitful and productive source of dialogue for the researcher.

\section{BIBLIOGRAPHIE}

Abric J-C., 1994. Pratiques sociales et représentations. Paris, PUF, 253 p.

Bailly A., Scariati R., 1990. L'humanisme en géographie. Paris, Economica, 172 p.

Bonnemaison J., 2004. La géographie culturelle. Paris, CTHS, 152 p.

Bonnet E., 2004. L'estuaire de la Seine : un territoire vulnérable face aux risques industriels.

Mappemonde, vol. 4, $\mathrm{n}^{\circ} 76$, p. 1-6.

Claval P., 2003. Géographie culturelle, une nouvelle approche des sociétés et des milieux. Paris, Armand Colin, $287 \mathrm{p}$.

Corlay J-P., 1995. Géographie sociale, géographie du littoral. Norois, n¹65, p. 247-265.

Di Méo G., 1998. Géographie sociale et territoires. Paris, Nathan, 320 p.

Di Méo G., 1991. L'Homme, la Société, l'Espace. Paris, Anthropos, 319 p.

Downs R., Stea D., 1973. Image and Environment. Chicago, Edward Arnold Editions, p. 439.

Ferras R., 1993. Les Modèles Graphiques en Géographie. Paris, Economica/Reclus, 112 p.

Frémont A., 1999. La région, espace vécu. Paris, Flammarion, 288 p.

Gould P., White R., 1974. Mental Maps. New York, Penguin Books, 187 p.

Gould P., White R., 1984. Cartes Mentales, traduit de l'anglais par A. Perroud et M. Roten. Fribourg, Editions Universitaires de Fribourg Suisse, $169 \mathrm{p}$.

Gumuchian H., 1991. Représentations et Aménagement du Territoire. Paris, Anthropos-Economica, $143 \mathrm{p}$.

Lynch K., 1960. The Image of the City. Cambridge, The MIT Press, $194 \mathrm{p}$.

Mc Kenna J., Quinn R.J., Donnelly D.J., Cooper J.A.G., 2008. Accurate Mental Maps as an Aspect of Local Ecological Knowledge (LEK) : a Case Study from Lough Neagh, Northern Ireland. Ecology and Society, $n^{\circ} 13, \mathrm{p} .1-23$.

Moser G., Weiss K., 2003. Espaces de vie. Aspects de la relation homme-environnement. Paris, Armand Colin, 396 p. 
Paulet J-P., 2002. Les représentations mentales en géographie. Paris, Anthropos, 152 p.

Péron F., 2005. Fonctions sociales et dimensions subjectives des espaces insulaires (à partir de l'exemple des îles du Ponant). Annales de géographie, vol. 4, nº 644, p. 422- 436.

Staszak J-F., 2003. Carte mentale. In Lévy J., Lussault M. (dir.), Dictionnaire de la géographie et de l'espace des sociétés. Paris, Belin, p. 132-133.

\section{NOTES}

1. Criticism of a confusion subject-object, of the subjectivity and the empathy of the researcher, and at least of a lack of rigor (Brunet, Pouliot, Berque in Bailly et al., 1990, pp. 156-157)

2. Mental representations in geography

3. Cultural geography. A new approach of societies and milieux

4. «Se reconnaître en ville : cartes mentales du Havre ", fig. 15 p. 116 ; «L'orientation chez les Yurok », fig. 16 p. 118 et «L'orientation chez les Aymara et les Incas », fig. 17 p. 119, in Claval, 2003.

5. If we refer to all the works related to mind maps and mentioned in bibliography

6. The restricted surface of the Netherlands lends itself particularly well to such a demarcation. of course, the national scale doesn't allow a demarcation within about a meter. Yet, the limits proposed by the interviewees did not express more than that degree of precision, and were always connected to geomorphologic or topographic units, easily recognizable.

7. Plan created following the dramatic tidal floods of 1953, in order to protect definitively the Dutch population against marine submersion. (See the poster 'Engineers are 'greener and greener'. Evolution of the thinking of engineers in charge of Dutch coastal management').

\section{RÉSUMÉS}

Après avoir été principalement utilisées en géographie urbaine, puis quelque peu mises de côté par les géographes, les cartes mentales font désormais l'objet d'un regain d'intérêt, en particulier dans le champ de la géographie de l'environnement. Appliquées à l'espace littoral et employées en complément de l'entretien, elles se révèlent être non seulement un bon outil de recueil des représentations spatiales, mais aussi une aide précieuse pour leur analyse. Cet article s'appuie sur l'exemple de l'utilisation des cartes mentales dans le poster scientifique Des ingénieurs de plus en plus « verts». Évolution du regard des ingénieurs en charge de la gestion du littoral néerlandais, lauréat du concours organisé par le forum de l'École Doctorale de Géographie de Paris de 2011.

After having been mainly used in urban geography, then cast aside by the geographers, mental maps are now the object of renewed interest, particularly in the field of environmental geography. Applied to the coast, and used as a supplement to the interview, these maps are not only of great assistance in collecting spatial representations, but also helpful in analyzing them. This article uses the example of the integration of mental maps in the scientific poster "Des ingénieurs de plus en plus “verts". Évolution du regard des ingénieurs en charge de la gestion du littoral néerlandais"(Engineers are 'greener and greener'. Evolution of the thinking of engineers 
in charge of Dutch coastal management.), prize-winner of the competition organized by the Paris Doctoral School of Geography Forum in 2011.

INDEX

Mots-clés : carte mentale, ingénieurs, littoral, Pays-Bas, représentations

Keywords : coast, engineers, mind maps, representations, the Netherlands

\section{AUTEUR}

\section{SERVANE GUEBEN-VENIÈRE}

Servane Gueben-Vénière est doctorante en géographie, université Paris I/UMR 8586 PRODIG. Elle a publié :

Gueben-Venière S., Goeldner-Gianella L., Decroix G., 2010. Face au changement climatique, les polders des Pays-Bas ont-ils un avenir ? Grande Europe, La Documentation Française, n¹9, p. 1-11. servaneveniere@yahoo.fr 